\title{
Direct Sequencing of the Polymerase Chain Reaction- Amplified 16S rRNA Gene of Flavobacterium gondwanense sp. nov. and Flavobacterium salegens sp. nov., Two New Species from a Hypersaline Antarctic Lake
}

\author{
S. J. DOBSON, ${ }^{1 *}$ R. R. COLWELL, ${ }^{2}$ T. A. MCMEEKIN, ${ }^{1}$ AND P. D. FRANZMANN ${ }^{1}$ \\ Department of Agricultural Science and Cooperative Research Centre for the Antarctic and Southern Ocean \\ Environment, University of Tasmania, Box 252C, Hobart, Tasmania 7001, Australia, ${ }^{1}$ and Maryland
} Biotechnology Institute, College Park, Maryland 20742

\begin{abstract}
Phenotypic data and phospholipid ester-linked fatty acid profiles indicate that pigmented bacterial strains isolated from a hypersaline Antarctic lake are members of the "flavobacterium-bacteroides" phylum and may represent new taxa. Nearly complete 16S rRNA sequences were obtained for representative strains by directly sequencing the polymerase chain reaction-amplified 16S rRNA gene. Sequence signatures confirmed that these organisms were members of the flavobacterium-bacteroides phylum. A phylogenetic analysis, in which the sequences of the Antarctic strains were compared with a large number of sequences available for members of the flavobacterium-bacteroides phylum, showed that the Antarctic strains were phylogenetically distinct. The new species cluster with a group of organisms that contains the type species of the genus Flavobacterium, Flavobacterium aquatile. Two new species are described, for which the names Flavobacterium gondwanense and Flavobacterium salegens are proposed; strains ACAM 44 (= DSM 5423) and ACAM 48 (= DSM 5424) are the type strains of $F$. gondwanense and $F$. salegens, respectively.
\end{abstract}

Moderately halophilic orange- and yellow-pigmented bacteria are readily cultured from Organic Lake, a hypersaline meromictic lake in the Vestfold Hills region of the Australian Antarctic Territory. Several strains of these pigmented bacteria have been characterized phenotypically (2). These strains were gram negative and nonmotile, had aerobic metabolism and DNA $\mathrm{G}+\mathrm{C}$ contents ranging from 35 to 41 $\mathrm{mol} \%$, and were considered probable members of the genus Flavobacterium (2). Phospholipid ester-linked fatty acid profiles revealed high levels of branched-chain fatty acids and the presence of branched-chain hydroxy fatty acids (20). These features are characteristic of members of the genera Flavobacterium and Cytophaga and related bacteria $(11,16)$.

In a numerical taxonomic study (2), the Antarctic strains formed two phena which did not include any of the reference organisms belonging to the genera Flavobacterium, Cytophaga, and Flectobacillus. This suggested that the Antarctic strains may be new species; however, the results were inconclusive because the salinity of the media employed in the study limited the choice of reference strains to marine and halotolerant species. A comparison with the phenotypes of several other species was precluded because of the variability of expression of some characteristics associated with high salinity. Genotype is independent of growth conditions; thus, genotype comparisons overcome the limitations of a comparative phenotypic study. In addition, genotypic data are phylogenetically informative.

The taxonomy of organisms placed in the genera Flavobacterium and Cytophaga and related genera, such as the genera Flexibacter and Microscilla, has been problematic and has undergone several revisions $(11,16)$. Progress has been made toward an understanding of the taxonomic relationships among these organisms; this progress has resulted from chemotaxonomic studies, nucleic acid hybridization

${ }^{*}$ Corresponding author. studies, and 16S rRNA studies $(11,16,25,27,29)$. However, the taxonomic status of these genera is still unsatisfactory. Phylogenetic relationships derived from molecular data are considered the basis for the development of a stable taxonomy for prokaryotes (26). In this study, the 16S rRNA sequences were determined for representative strains of the two Antarctic phena mentioned above, and two new species, Flavobacterium gondwanense (with type strain ACAM 44) and Flavobacterium salegens (with type strain ACAM 48), are described below.

\section{MATERIALS AND METHODS}

Microorganisms. Strain ACAM $44^{\mathrm{T}}$ (= DSM $5423^{\mathrm{T}}$; DSM is the Deutsche Sammlung von Mikroorganismen und Zellkulturen $\mathrm{GmbH}$, Braunschweig, Germany) ( $\mathrm{T}=$ type strain) and strain ACAM $48^{\mathrm{T}}$ (= DSM $5424^{\mathrm{T}}$ ) were obtained from the Australian Collection of Antarctic Microorganisms (ACAM), University of Tasmania, Hobart, Australia. The strains were grown in marine broth (Difco) at $25^{\circ} \mathrm{C}$.

DNA isolation and PCR amplification. DNA was extracted by the rapid guanidium thiocyanate method of Pitcher et al. (15), treated with RNase, and reprecipitated. The polymerase chain reaction (PCR) (18) was performed by using a GeneAmp kit (Perkin-Elmer Cetus) and primers $\mathrm{A}$ and $\mathrm{H}^{*}$ as described by Edwards et al. (3), which amplify the region from position 29 to position 1521 (Escherichia coli numbering) of the 16S rRNA genes of a broad range of organisms belonging to the domain Bacteria. The thermal profile used for amplification was based on the thermal profile of Edwards et al. (3); the annealing temperature was increased to $55^{\circ} \mathrm{C}$ to reduce the generation of nonspecific products. The amount of template used in the reaction mixture was reduced to $10 \mathrm{ng} / 100-\mu \mathrm{l}$ reaction mixture and the amount of primers used was reduced to $50 \mathrm{pmol} / 100-\mu \mathrm{l}$ reaction mixture without detriment. The PCR products were separated by agarose 
TABLE 1. Evolutionary distances determined for Flavobacterium gondwanense, Flavobacterium salegens, and some members of the flavobacterium-bacteroides phylum

\begin{tabular}{|c|c|c|c|c|c|c|c|c|c|c|c|}
\hline \multirow[b]{2}{*}{ Species } & \multicolumn{11}{|c|}{ Evolutionary distances $^{a}$} \\
\hline & 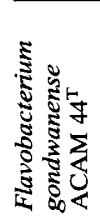 &  &  & 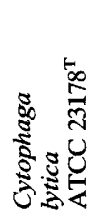 & 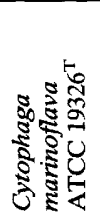 & 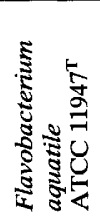 & 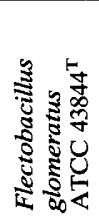 & 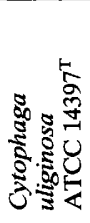 & 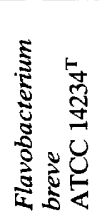 & 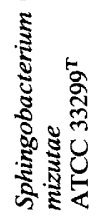 & 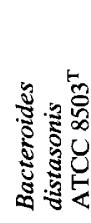 \\
\hline Flavobacterium salegens & 0.091 & & & & & & & & & & \\
\hline Cytophaga latercula & 0.095 & 0.080 & & & & & & & & & \\
\hline Cytophaga lytica & 0.105 & 0.112 & 0.082 & & & & & & & & \\
\hline Cytophaga marinoflava & 0.113 & 0.105 & 0.106 & 0.104 & & & & & & & \\
\hline Flavobacterium aquatile & 0.125 & 0.111 & 0.113 & 0.114 & 0.115 & & & & & & \\
\hline Flectobacillus glomeratus & 0.135 & 0.111 & 0.120 & 0.120 & 0.138 & 0.117 & & & & & \\
\hline Cytophaga uliginosa & 0.135 & 0.143 & 0.138 & 0.104 & 0.120 & 0.135 & 0.143 & & & & \\
\hline Flavobacterium breve & 0.160 & 0.168 & 0.157 & 0.157 & 0.156 & 0.152 & 0.175 & 0.176 & & & \\
\hline Sphingobacterium mizutae & 0.236 & 0.238 & 0.237 & 0.219 & 0.233 & 0.246 & 0.244 & 0.206 & 0.229 & & \\
\hline Bacteroides distasonis & 0.241 & 0.233 & 0.242 & 0.241 & 0.255 & 0.253 & 0.241 & 0.239 & 0.253 & 0.230 & \\
\hline Cytophaga hutchinsonii & 0.262 & 0.254 & 0.245 & 0.251 & 0.254 & 0.247 & 0.261 & 0.265 & 0.229 & 0.225 & 0.237 \\
\hline
\end{tabular}

${ }^{a}$ Evolutionary distances were calculated by using the Jukes-Cantor equation.

gel electrophoresis, and the $16 \mathrm{~S}$ ribosomal DNA product was recovered from the gel by using GeneClean (Bio 101).

Sequencing of PCR product. The $16 \mathrm{~S}$ ribosomal DNA PCR product was sequenced by using a Sequenase kit (United States Biochemical Corp.). The standard protocol $(19,24)$ was modified by including $1 \mu$ l of $20 \%$ Nonidet P-40 (Sigma) in the annealing mixture and denaturing the annealing mixture by boiling, followed by snap-freezing in a dry iceethanol bath (1). The sequencing reaction was performed with 0.5 to $1.0 \mu \mathrm{g}$ of the isolated 16S ribosomal DNA PCR product. Use of a smaller amount of template often resulted in a sequence ladder of poorer quality. Primers for the regions from positions 8 to 28,1542 to 1522 (3) 128 to 109 (22), 518 to 536,908 to $928(12), 684$ to 704,1100 to 1115 , and 1387 to 1407 (4) were used for sequencing. Sequences were obtained from the priming regions from positions 518 to 536 and 708 to 684 in both directions. Primer CACACGTGCTA CAATGGTAG for the region from position 1220 to position 1229 was used to complete the sequencing of strain ACAM $44^{\mathrm{T}}$. This primer, which was designed to be specific for the Antarctic flavobacteria, was a modification of the primer of Stackebrandt and Charfreitag (22).

Phylogenetic analysis. The sequences were aligned manually with a group of prealigned sequences from several organisms belonging to the "flavobacterium-bacteroides" phylum, which were available from the Illinois RNA data base (14), taking into account secondary-structure considerations. Sequences for the following organisms were obtained from the Illinois RNA data base (ATCC is the American Type Culture Collection, Rockville, Md.): Cytophaga latercula ATCC $23177^{\mathrm{T}}$, Cytophaga lytica ATCC $23178^{\mathrm{T}}$, Flavobacterium odoratum ATCC $4651^{\mathrm{T}}$, Bacteroides distasonis ATCC $8503^{\mathrm{T}}$, Sphingobacterium mizutae ATCC $33299^{\mathrm{T}}$, Cytophaga heparina ATCC $13125^{\mathrm{T}}$, Flectobacillus marinus ATCC 43824, Cytophaga hutchinsonii ATCC $33406^{\mathrm{T}}$, Flectobacillus major ATCC $29496^{\mathrm{T}}$, Cytophaga fermentans ATCC $19072^{\mathrm{T}}$, Flavobacterium breve ATCC 14234, Flavobacterium indoltheticum ATCC $27950^{\mathrm{T}}$, Flavobacterium gleum ATCC $35910^{\mathrm{T}}$, Cytophaga aquatilis ATCC $29551^{\mathrm{T}}$, Flavobacterium aquatile ATCC $11947^{\mathrm{T}}$, Flexibacter aggregans ATCC $23162^{\mathrm{T}}$, Flectobacillus glomeratus ATCC
43844 T, “Antarcticum vesiculatum," Cytophaga uliginosa ATCC $14397^{\mathrm{T}}$, and Cytophaga marinoflava ATCC $19326^{\mathrm{T}}$.

The Jukes-Cantor equation was used to calculate evolutionary distances between pairs of organisms (Table 1) by using the DNADIST program of the PHYLIP v3.4 package (5). A tree estimating the phylogenetic relationships among the organisms was derived by using the FITCH program of the same package, random-order input of sequences, and the global rearrangement option. An additional tree for a subset of the organisms was derived by parsimony analysis, using the branch and bound method available in the PAUP program (23).

Respiratory quinones. Respiratory quinones were extracted and analyzed as described previously (6).

Nucleotide sequence accession numbers. The sequences for strains ACAM 44 ${ }^{\mathrm{T}}$ and ACAM $48^{\mathrm{T}}$ have been deposited in the GenBank data base under accession numbers M92278 and M92279, respectively. The GenBank accession numbers for the sequences obtained from the Illinois RNA data base are as follows: $C$. latercula ATCC $23177^{\mathrm{T}}$, M58769; C. lytica ATCC 23178 ${ }^{\mathrm{T}}$, M62796; Flavobacterium odoratum ATCC $4651^{\mathrm{T}}$, M58777; B. distasonis ATCC $8503^{\mathrm{T}}$, M86695; S. mizutae ATCC $33299^{\mathrm{T}}$, M58796; C. heparina ATCC $13125^{\mathrm{T}}$, M11657; Flectobacillus marinus ATCC 43824, M62788; $C$. hutchinsonii ATCC $33406^{\mathrm{T}}$, M58768; Flectobacillus major ATCC $29496^{\mathrm{T}}$, M62787; C. fermentans ATCC $19072^{\mathrm{T}}$, M58766; Flavobacterium breve ATCC 14234, M59052; Flavobacterium indoltheticum ATCC 27950 ${ }^{\mathrm{T}}$, M58774; Flavobacterium gleum ATCC $35910^{\mathrm{T}}$, M58772; C. aquatilis ATCC 29551 ${ }^{\mathrm{T}}$, M58764; Flavobacterium aquatile ATCC $11947^{\mathrm{T}}$, M62797; Flexibacter aggregans ATCC $23162^{\mathrm{T}}$, M58780; Flectobacillus glomeratus ATCC 43844 ${ }^{\mathrm{T}}$, M58775; "Antarcticum vesiculatum," M61002; C. uliginosa ATCC $14397^{\mathrm{T}}$, M62799; and C. marinoflava ATCC $19326^{\mathrm{T}}$, M58770.

\section{RESULTS AND DISCUSSION}

Bachmann et al. (1) found that addition of Nonidet P-40 improved the direct sequencing of a short double-stranded (115-bp) PCR product. This technique worked well with the 


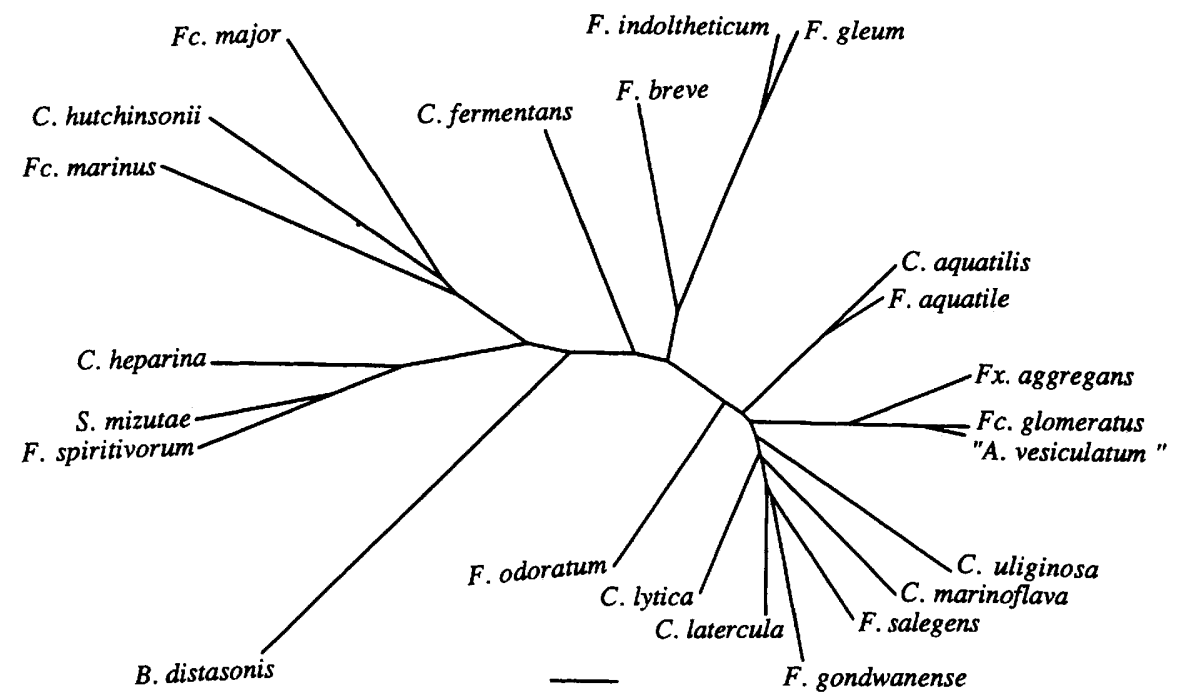

FIG. 1. Tree derived by additive analysis, using the FITCH program in the PHYLIP v3.4 package. The tree shows the phylogenetic relationships among Flavobacterium gondwanense ACAM $44^{\mathrm{T}}$, Flavobacterium salegens ACAM $48^{\mathrm{T}}$, and some members of the flavobacterium-bacteroides phylum. Bar $=0.02$ evolutionary distance unit, as calculated by the Jukes-Cantor equation. Abbreviations: $F$, Flavobacterium; Fc., Flectobacillus; C., Cytophaga; S., Sphingobacterium; B., Bacteroides; A., Antarcticum; Fx., Flexibacter.

16S ribosomal DNA PCR product, obviating the need to use a ${ }^{32} \mathrm{P}$-labelled radionucleotide, to clone the $\mathrm{PCR}$ product or to generate a single-stranded template. Bachmann et al. (1) included Nonidet $\mathrm{P}-40$ in all additions to the reaction mixture. We found that a single addition to the annealing reaction was sufficient. There was some variation in the quality of the sequence depending on the template-primer combination.

The 16S rRNA sequences of strains ACAM $44^{\mathrm{T}}$ and ACAM $48^{\mathrm{T}}$ contained the definitive flavobacterial signatures identified by Woese and colleagues $(27,28)$ that unequivocally place these organisms in the flavobacterium-bacteroides phylum. These features include $\mathrm{A}$ at position 38 , a G . C base pair at positions 290 to 310 , a loop size of 5 at positions 416 to 427 , a loop of 4 bases and a 6-pair stem at positions 455 to $477, \mathrm{U}$ at position $570, \mathrm{~A}$ at position $866, \mathrm{AU}$ at positions 995 and 996, $\mathrm{A}$ at position 1045, a deletion in the loop and a base added at position 1074 in the stem-loop helix at positions 1161 to 1175 , and a deletion of 4 pairs at positions 1436 to 1465 (compared with the $E$. coli stem). An additional signature at positions 1530 to 1533 was not determined because it occurs within the PCR primer site. The sequences of strains ACAM $44^{\mathrm{T}}$ and ACAM $48^{\mathrm{T}}$ contain a C at position 1205, which is a signature of the genus Bacteroides and some groups of flavobacteria.

The major respiratory lipoquinone in strains ACAM $44^{\mathrm{T}}$ and ACAM $48^{\mathrm{T}}$ was menaquinone 6 . The presence of menaquinones is a characteristic of aerobic, pigmented bacteria belonging to the flavobacterium-bacteroides phylum (16).

The additive and parsimony methods of tree construction produced trees with similar topologies (Fig. 1 and 2). Some variation in topology occurs among the closest relatives of the Antarctic flavobacteria. The tree derived from the parsimony analysis may be considered a better representation of the pairwise distances (Table 1) because it shows that strain ACAM $48^{\mathrm{T}}$ is more closely related to $C$. latercula than to strain ACAM $44^{\mathrm{T}}$. Because of computational limitations fewer species were included in the parsimony analysis.

On the phylogenetic trees the Antarctic flavobacteria grouped with the members of a branch of the flavobacterium-bacteroides phylum that contains organisms isolated from marine and freshwater habitats and a single urinary tract species, Flavobacterium odoratum, on the periphery (Fig. 1 and 2). The members of this branch are currently assigned to five genera, Cytophaga, Flavobacte-

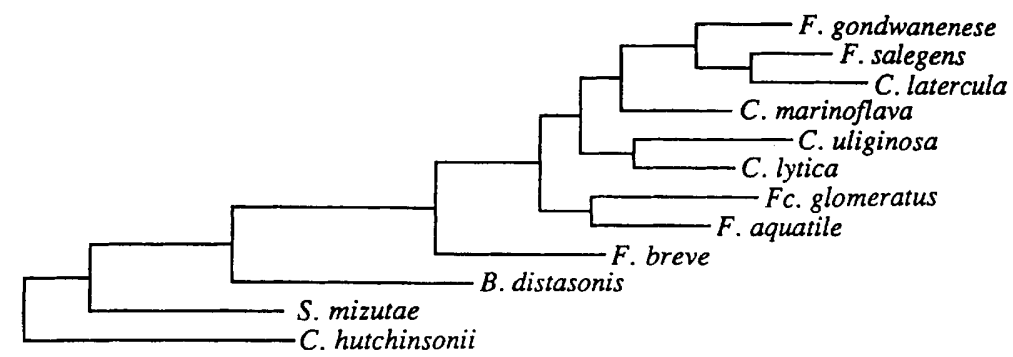

FIG. 2. Most parsimonious tree derived by using the branch and bound method in the PAUP program, showing the phylogenetic relationships among Flavobacterium gondwanense ACAM $44^{\mathrm{T}}$, Flavobacterium salegens ACAM $48^{\mathrm{T}}$, and some members of the flavobacterium-bacteroides phylum. Abbreviations: F., Flavobacterium; C., Cytophaga; Fc., Flectobacillus; B., Bacteroides; S., Sphingobacterium. 
TABLE 2. Some characteristics which differentiate the Antarctic flavobacterial species, Flavobacterium gondwanense and Flavobacterium salegens, and other flavobacterial species for which chemotaxonomic and 16S rRNA sequence data are not available

\begin{tabular}{|c|c|c|c|c|c|c|c|c|c|c|c|c|c|}
\hline \multirow{2}{*}{ Species } & \multirow[b]{2}{*}{ 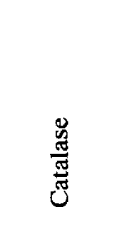 } & \multirow[b]{2}{*}{ 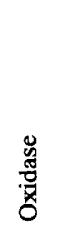 } & \multirow{2}{*}{  } & \multirow{2}{*}{ 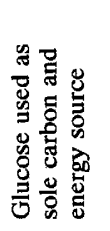 } & \multicolumn{4}{|c|}{ Degradation of: } & \multirow{2}{*}{ 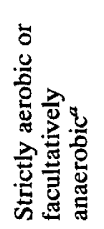 } & \multirow[b]{2}{*}{ 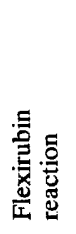 } & \multirow{2}{*}{ 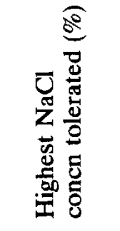 } & \multirow{2}{*}{ 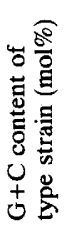 } & \multirow{2}{*}{ 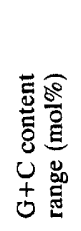 } \\
\hline & & & & & 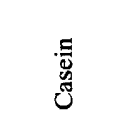 & 营 & 妾 & $\begin{array}{l}\overline{0} \\
\text { 苟 } \\
\text {. }\end{array}$ & & & & & \\
\hline Flavobacterium gondwanense & $+(9 / 11)^{b}$ & + & - & - & $-(10 / 11)$ & - & - & + & $\mathbf{a}$ & - & $15(9 / 11)$ & 39 & $35-39^{c}$ \\
\hline Flavobacterium salegens & + & + & - & $-(4 / 5)$ & - & - & - & + & a $(4 / 5)$ & - & $20(3 / 5)$ & 41 & $39-41^{c}$ \\
\hline Cytophaga aurantiaca ${ }^{d}$ & - & + & $\mathrm{ND}^{e}$ & + & ND & - & ND & - & a & - & ND & 42 & ND \\
\hline Cytophaga salmonicolor & + & ND & ND & + & ND & - & - & + & f & ND & 3 & 37 & ND \\
\hline Cytophaga agarovorans & + & ND & ND & + & ND & + & - & + & f & ND & 3 & 41 & ND \\
\hline Cytophaga saccharophila & - & - & + & + & - & + & - & + & a & + & 2 & 32 & $32-36$ \\
\hline Cytophaga aprica & - & + & + & - & + & + & - & + & a & - & 6 & 35 & $35-37$ \\
\hline Cytophaga pectinovora & + & + & - & + & + & - & + & + & a & + & 1 & 34 & ND \\
\hline Cytophaga psychrophila & - & + & - & - & + & - & - & - & a & + & 0.8 & 32 & 32 \\
\hline Cytophaga marina & + & + & - & - & + & - & - & - & $\mathbf{a}$ & ND & ND & 31 & $31-32$ \\
\hline Cytophaga succinicans & + & + & ND & + & + & - & - & + & $\mathrm{f}$ & - & ND & 38 & 38 \\
\hline Cytophaga columnaris & + & + & + & - & + & - & - & - & a & + & 0.5 & 30 & ND \\
\hline Flexibacter filiformis & - & + & - & ND & & ND & + & - & a & + & 0.3 & 47 & $46-47$ \\
\hline
\end{tabular}

${ }^{a}$ a, strictly aerobic; $\mathrm{f}$, facultatively anaerobic.

${ }^{b}$ Reaction of the type strain. The numbers in parentheses are the number of strains which had the reaction indicated/number of strains tested.

${ }^{c} \mathrm{G}+\mathrm{C}$ content range based on three strains (2).

$d$ The data for the non-Antarctic species are from reference 16

$e$ ND, no data available.

rium, Flexibacter, Flectobacillus and "Antarcticum," and include the type species of the genus Flavobacterium, Flavobacterium aquatile.

Flavobacterium aquatile has been considered atypical of the group of species which currently are placed in the genus Flavobacterium. A proposal was made to the Judicial Commission to change the Flavobacterium type species to Flavobacterium breve; however, this proposal was rejected, and Flavobacterium aquatile retains the status of type species $(10,11)$. Holmes (9) did not include Flavobacterium aquatile among the species belonging to the genus on a recent list, although he noted that the name Flavobacterium should remain with this organism when new genera are created for the other species. Reichenbach included Flavobacterium aquatile among the Cytophaga-like bacteria (16).

The branch in which the Antarctic flavobacteria fall contains several species of the genus Cytophaga. Gliding motility has been observed for most of these organisms, but not for C. latercula (16). Gliding motility or spreading growth has not been observed for the Antarctic flavobacteria, although their cell morphology and cell arrangement are similar to the cell morphology and cell arrangement of other members of this group. The type species of the genus Cytophaga, C. hutchinsonii, is not closely related to this group of organisms; therefore, placement of the Antarctic flavobacteria in the genus Cytophaga is not warranted.

The Antarctic flavobacteria are the first moderately halophilic flavobacteria to be described, and they have fatty acid profiles that are unique within the flavobacteria. Strain ACAM $44^{\mathrm{T}}$ contains anteiso-15:0 as the major fatty acid rather than iso-15:0 and also contains anteiso-15:1w10c. Strain ACAM $48^{\mathrm{T}}$ contains 16:1w7c. Both strains also contain small amounts of 3-OH anteiso-15:0 and 3-OH anteiso17:0 (20). The Antarctic flavobacteria represent distinct taxa at least at the species level, given the estimated evolutionary distances between them and the other species of flavobac- teria. They may represent novel genera. However, the fatty acid profiles of several members of the branch in which they occur have not been determined, and the significance of halophilism in delimiting taxa at the genus level has not been established.

While a large data base of flavobacterial 16S rRNA sequences now exists, the sequences of representatives of some species have not been determined. One of these species, Flavobacterium multivorum, contains sphingophospholipids. Flavobacteria which contain this lipid, such as $S$. mizutae and $C$. heparina, form a phylogenetically distinct branch. Chemotaxonomic data for the other species are not available, so these organisms are compared with the proposed Antarctic species on the basis of significant phenotypic features in Table 2. The expression of some characteristics, such as antibiotic susceptibility (13), motility (17), urease activity, reduction of nitrate, and production of acid from carbohydrates (8), has been shown to vary depending on the salt concentrations of the test media; however, we believe that differentiation between the Antarctic flavobacteria and the other species on the basis of characteristics such as the presence of catalase, the capacity to utilize glucose as a sole carbon and energy source, the presence of flexirubin (as determined by the KOH test), and halotolerance, is a legitimate indication of phenotypic distinction at the species level. Cytophaga marina exhibits the closest phenotypic similarity to the Antarctic species across the range of characteristics studied; however, $C$. marina has a significantly lower DNA G+C content than the Antarctic species.

The levels of 16S rRNA sequence similarity between member species of a genus differ substantially for many well-defined genera and range from 78 to $95 \%$ (21). The levels of sequence similarity between strains ACAM $44^{\mathrm{T}}$ and ACAM $48^{\mathrm{T}}$ and Flavobacterium aquatile are 89 and $90 \%$, respectively (not adjusted by the Jukes-Cantor equation). Given the nomenclatural necessity that Flavobacterium 
aquatile must remain the type species of the genus Flavobacterium, the Antactic flavobacteria are assigned to this genus as two new species, Flavobacterium gondwanense and Flavobacterium salegens, as described below.

Description of Flavobacterium gondwanense sp. nov. Flavobacterium gondwanense (gond. wa. nen'se. L. adj. gondwanense, of Gondwanaland or Gondwana, one of the two ancient supercontinents comprising what are now Africa, South America, Australia, Antarctica, and the Indian subcontinent [7]) cells are rod shaped and occur singly, in pairs, and in short chains. Cell widths range from 0.4 to $0.8 \mu \mathrm{m}$, and cell lengths range from 1.7 to $11.7 \mu \mathrm{m}$. Cells are gram negative and nonmotile and have strictly aerobic metabolism. Colonies on solid media are orange, circular, and entire. Members of this species are moderately halophilic and grow optimally in media containing 5\% total salts. Pigment production is inhibited on media containing Tween 20. Members of this species produce cytochrome oxidase, phosphatase, and DNase and hydrolyze esculin and starch. They do not reduce nitrate to nitrite, produce $\beta$-galactosidase, ornithine decarboxylase, or lysine decarboxylase, utilize malonate, grow in the presence of $20 \% \mathrm{NaCl}$, grow at $37^{\circ} \mathrm{C}$, or hydrolyze chitin or agar. They do not produce spreading growth on low-peptone agar. No bathochromic shift is observed when $20 \% \mathrm{KOH}$ is added to colonies. All strains grow in the presence of $10 \% \mathrm{NaCl}$. The growth of all members of the species is not stimulated by a wide range of single carbon sources, including proline, sucrose, L-rhamnose, salicin, D-glucose, D-galactose, glycine, hydroxy-Lproline, D-mannose, D-gluconic acid, maltose, serine, D-trehalose, tryptophan, alanine, cysteine, histidine, L-arabinose, tyrosine, glycerol, inositol, isoleucine, maltose, leucine, and valine. Acid is not produced from galactose by any strain. All members of the species are susceptible to novobiocin ( 30 $\mu \mathrm{g})$, chloramphenicol $(30 \mu \mathrm{g})$, and erythromycin $(15 \mu \mathrm{g})$ and resistant to vibriostatic agent $0 / 129(10 \mu \mathrm{g})$, polymyxin $\mathrm{B}$ $(300 \mathrm{U})$, and gentamicin $(10 \mu \mathrm{g})$. The $\mathrm{G}+\mathrm{C}$ contents of this species, determined for three strains, range from 35 to 39 mol\%. The type strain is strain ACAM $44^{\mathrm{T}}$, which has a $\mathrm{G}+\mathrm{C}$ content of $39 \mathrm{~mol} \%$. Distinctive features of the fatty acid profile of strain ACAM $44^{\mathrm{T}}$ are the occurrence of anteiso-15:0 as the major fatty acid and the presence of anteiso-15:1w10c, 3-OH anteiso-15:0, and 3-OH anteiso17:0. The major respiratory lipoquinone is menaquinone 6 . The species is represented by 11 strains (strains ACAM 1, ACAM 40, ACAM 41, ACAM 43, ACAM 44, ACAM 45, ACAM 46, ACAM 49, ACAM 51, ACAM 56, and ACAM 62). Characteristics which vary among strains belonging to this species are shown in Table 3.

Description of Flavobacterium salegens sp. nov. Flavobacterium salegens (sal'e. gens. L. n. sal, salt; L. adj. egens, needy; L. adj. salegens, needing salt) cells are rod shaped and occur singly, in pairs, and sometimes in chains. Cell widths range from 0.5 to $0.8 \mu \mathrm{m}$, and cell lengths range from 1.2 to $11.5 \mu \mathrm{m}$. Cells are gram negative and nonmotile. Members of the species are aerobic. Colonies on solid media are yellow, circular, entire, and convex. Members of this species are moderately halophilic and grow optimally in media containing 5\% total salts. Growth on Tween 20containing agar inhibits pigment production. All members of this species produce catalase, cytochrome oxidase, phosphatase, DNase, and $\beta$-galactosidase, reduce nitrate to nitrite, grow in the presence of $15 \% \mathrm{NaCl}$, hydrolyze Tween 20 , starch, and esculin, and liquefy gelatin. No strain produces ornithine decarboxylase or lysine decarboxylase, utilizes malonate, hydrolyzes chitin, agar, or casein, or pro-
TABLE 3. Characteristics of the type strain which vary among strains belonging to Flavobacterium gondwanense ${ }^{a}$

\begin{tabular}{|c|c|c|}
\hline Characteristic & $\begin{array}{l}\text { Reaction of type } \\
\text { strain ACAM } 44\end{array}$ & $\begin{array}{l}\text { No. of strains } \\
\text { with same result } \\
\text { as type strain/no. } \\
\text { of strains tested }\end{array}$ \\
\hline \multicolumn{3}{|l|}{ Growth at: } \\
\hline $\mathrm{pH} 4$ & - & $2 / 7$ \\
\hline pH 9 & + & $9 / 10$ \\
\hline Catalase & + & $8 / 10$ \\
\hline Urease & + & $4 / 10$ \\
\hline \multicolumn{3}{|l|}{ Susceptible to: } \\
\hline Ampicillin $(30 \mu \mathrm{g})$ & + & $9 / 10$ \\
\hline Streptomycin $(10 \mu \mathrm{g})$ & - & $9 / 10$ \\
\hline Tetracycline $(30 \mu \mathrm{g})$ & + & $6 / 10$ \\
\hline Cephalothin $(30 \mu \mathrm{g})$ & + & $9 / 10$ \\
\hline Nalidixic acid $(30 \mu \mathrm{g})$ & - & $9 / 10$ \\
\hline Neomycin $(30 \mu \mathrm{g})$ & - & $8 / 10$ \\
\hline Penicillin G (10 U) & + & $9 / 10$ \\
\hline $\mathrm{HgCl}_{2}(0.02 \%$, wt/vol $)$ & + & $3 / 9$ \\
\hline Tween 80 & + & $7 / 8$ \\
\hline Tween 20 & + & $8 / 9$ \\
\hline \multicolumn{3}{|l|}{ Growth at: } \\
\hline$-5^{\circ} \mathrm{C}$ & - & $9 / 10$ \\
\hline $0^{\circ} \mathrm{C}$ & $-1 t^{b}$ & $8 / 10$ \\
\hline \multicolumn{3}{|l|}{ Growth in the presence of: } \\
\hline $0 \% \mathrm{NaCl}^{c}$ & + & $7 / 9$ \\
\hline $15 \% \mathrm{NaCl}$ & + & $7 / 10$ \\
\hline \multicolumn{3}{|l|}{ Acid production from: } \\
\hline Arabinose & - & $6 / 7$ \\
\hline Maltose & - & $2 / 5$ \\
\hline Mannose & - & $6 / 7$ \\
\hline Lactose & - & $7 / 9$ \\
\hline Glucose & - & $3 / 8$ \\
\hline Sucrose & - & $7 / 9$ \\
\hline Fructose & - & $7 / 8$ \\
\hline Casein hydrolysis & - & $9 / 10$ \\
\hline Gelatin liquefaction & - & $4 / 10$ \\
\hline \multicolumn{3}{|l|}{ Colony width } \\
\hline$<1 \mathrm{~mm}$ & + & $8 / 9$ \\
\hline$>1 \mathrm{~mm}$ & - & $8 / 9$ \\
\hline Flat colonies & + & $9 / 10$ \\
\hline Convex colonies & - & $9 / 10$ \\
\hline \multicolumn{3}{|l|}{ Growth stimulated by: } \\
\hline Adonitol & - & $7 / 10$ \\
\hline Arginine & - & $7 / 10$ \\
\hline Fumarate & - & $8 / 10$ \\
\hline D-Xylose & - & $8 / 10$ \\
\hline Pyruvate & - & $7 / 10$ \\
\hline Asparagine & - & $7 / 10$ \\
\hline Raffinose & - & $8 / 10$ \\
\hline Succinate & - & $7 / 10$ \\
\hline Propionate & - & $7 / 10$ \\
\hline Lysine & - & $8 / 10$ \\
\hline Lactose & - & $9 / 10$ \\
\hline Cysteine & - & $9 / 10$ \\
\hline$\beta$-Hydroxybutyrate & - & $9 / 10$ \\
\hline Threonine & - & $9 / 10$ \\
\hline Ornithine & - & $9 / 10$ \\
\hline Fructose & - & $3 / 10$ \\
\hline Cell length $>2 \mu \mathrm{m}$ but $\leq 4 \mu \mathrm{m}$ & + & $7 / 10$ \\
\hline Cell length $>4 \mu \mathrm{m}$ but $<6 \mu \mathrm{m}$ & - & $7 / 10$ \\
\hline \multicolumn{3}{|l|}{ Alkaline reaction from: } \\
\hline Mannitol & $-1+$ & $1 / 10$ \\
\hline Galactose & - & $3 / 6$ \\
\hline Lactose & - & $8 / 9$ \\
\hline
\end{tabular}

${ }^{a}$ The test methods used are described in reference 2

$b-/+$, borderline result (for the purposes of comparison, the result was treated as a positive result).

${ }^{c}$ Other salts were present in the basal test medium. 
TABLE 4. Characteristics of the type strain which vary among strains belonging to Flavobacterium salegens ${ }^{a}$

\begin{tabular}{|c|c|c|}
\hline Characteristic & $\begin{array}{l}\text { Reaction of type } \\
\text { strain ACAM } 48\end{array}$ & $\begin{array}{l}\text { No. of strains } \\
\text { with same result } \\
\text { as type strain/no. } \\
\text { of strains tested }\end{array}$ \\
\hline Growth at $\mathrm{pH} 4$ & - & $1 / 2$ \\
\hline Urease & - & $1 / 3$ \\
\hline \multicolumn{3}{|l|}{ Susceptible to: } \\
\hline Tetracycline $(30 \mu \mathrm{g})$ & + & $2 / 4$ \\
\hline Bacitracin (10 U) & - & $3 / 4$ \\
\hline Nalidixic acid $(30 \mu \mathrm{g})$ & - & $3 / 4$ \\
\hline $\mathrm{HgCl}_{2}(0.02 \%, \mathrm{wt} / \mathrm{vol})$ & + & $3 / 4$ \\
\hline Tween 80 & + & $3 / 4$ \\
\hline Growth at $0^{\circ} \mathrm{C}$ & - & $0 / 4$ \\
\hline Growth in $20 \% \mathrm{NaCl}$ & + & $2 / 4$ \\
\hline \multicolumn{3}{|l|}{ Acid production from: } \\
\hline Lactose & + & $2 / 3$ \\
\hline Glucose & + & $1 / 2$ \\
\hline Sucrose & + & $2 / 3$ \\
\hline Anaerobic growth with nitrate & - & $3 / 4$ \\
\hline \multicolumn{3}{|l|}{ Colony width } \\
\hline$<1 \mathrm{~mm}$ & + & $1 / 4$ \\
\hline$>1 \mathrm{~mm}$ & - & $1 / 4$ \\
\hline \multicolumn{3}{|l|}{ Growth stimulated by: } \\
\hline Sucrose & + & $2 / 4$ \\
\hline Fumarate & + & $3 / 4$ \\
\hline Proline & + & $3 / 4$ \\
\hline Glucose & - & $3 / 4$ \\
\hline Pyruvate & + & $3 / 4$ \\
\hline Tryptophan & - & $2 / 4$ \\
\hline Raffinose & - & $2 / 4$ \\
\hline Succinate & - & $3 / 4$ \\
\hline Cellobiose & - & $1 / 4$ \\
\hline Alanine & - & $2 / 4$ \\
\hline Fructose & - & $2 / 4$ \\
\hline Cell length $\leq 2 \mu \mathrm{m}$ & - & $3 / 4$ \\
\hline Cell length $>2 \mu \mathrm{m}$ but $\leq 4 \mu \mathrm{m}$ & + & $1 / 4$ \\
\hline Cell length $>4 \mu \mathrm{m}$ but $\leq 6 \mu \mathrm{m}$ & - & $2 / 4$ \\
\hline
\end{tabular}

${ }^{a}$ The test methods used are described in reference 2.

duces spreading growth on low-peptone agar. No bathochromic shift is observed when $20 \% \mathrm{KOH}$ is added to colonies. The growth of all members of the species is stimulated by arginine, D-gluconic acid, pyruvate, maltose, ornithine, and lactose. The growth of all strains is not stimulated by adonitol, L-rhamnose, salicin, glycine, hydroxy-L-proline, D-mannose, D-xylose, serine, D-trehalose, L-asparganine, L-lysine, histidine, L-arabinose, cysteine, threonine, tyrosine, glycerol, inositol, isoleucine, maltose, leucine, and valine. All strains produce acid from L-arabinose, maltose, and mannitol and are susceptible to novobiocin $(30 \mu \mathrm{g})$, chloramphenicol $(30 \mu \mathrm{g})$, ampicillin $(10 \mu \mathrm{g})$, erythromycin $(15 \mu \mathrm{g})$, and cephalothin $(30 \mu \mathrm{g})$. All strains are resistant to vibriostatic agent $0 / 129(10 \mu \mathrm{g})$ and neomycin $(30 \mu \mathrm{g})$. The $\mathrm{G}+\mathrm{C}$ contents of this species, determined for three strains, range from 39 to $41 \mathrm{~mol} \%$.

The type strain is strain ACAM $48^{\mathrm{T}}$, which has a $\mathrm{G}+\mathrm{C}$ content of $41 \mathrm{~mol} \%$. Distinctive features of the fatty acid profile of strain ACAM $48^{\mathrm{T}}$ are the presence of $16: 1 w 7 \mathrm{c}$, 3-OH anteiso-15:0, and 3-OH anteiso-17:0. The major respiratory lipoquinone is menaquinone 6 . The species is represented by five strains (strains ACAM 2, ACAM 48 ${ }^{\mathrm{T}}$, ACAM 52, ACAM 53, and ACAM 54). Characteristics which vary among strains belonging to this species are shown in Table 4 .

\section{ACKNOWLEDGMENTS}

We thank Harry Burton of the Australian Antarctic Division for his interest in and support for this project, Gary Olsen for supplying sequence data from the Illinois RNA data base, and P. R. C. Weaver for providing advice about the correct Latin forms for the species names.

This study received funding from grants from the Australian Research Council and the Antarctic Science Advisory Committee, S.J.D. was supported by an Australian Postgraduate Research Award and a Fulbright Postgraduate Scholarship.

\section{REFERENCES}

1. Bachmann, B., W. Lüke, and G. Hunsmann. 1990. Improvement of PCR amplified DNA sequencing with the aid of detergents. Nucleic Acids Res. 18:1309.

2. Dobson, S. J., S. R. James, P. D. Franzmann, and T. A. McMeekin. 1991. A numerical taxonomic study of some pigmented bacteria isolated from Organic Lake, an Antarctic hypersaline lake. Arch. Microbiol. 156:56-61.

3. Edwards, U., T. Rogall, H. Blöcker, M. Emde, and E. C. Böttger. 1989. Isolation and direct complete nucleotide determination of entire genes. Characterization of a gene coding for $16 \mathrm{~S}$ ribosomal genes. Nucleic Acids Res. 17:7843-7853.

4. Embley, T. M., J. Smida, and E. Stackebrandt. 1988. Reverse transcriptase sequencing of $16 \mathrm{~S}$ ribosomal RNA from Faenia rectivirgula, Pseudonocardia thermophila and Saccharopolyspora hirsuta, three wall type IV actinomycetes which lack mycolic acids. J. Gen. Microbiol. 134:961-966.

5. Felsenstein, J. 1989. PHYLIP_phylogeny inference package (version 3.2). Cladistics 5:164-166.

6. Franzmann, P. D., and B. J. Tindall. 1990. A chemotaxonomic study of members of the family Halomonadaceae. Syst. Appl. Microbiol. 13:142-147.

7. Hanks, P. (ed.). 1986. Collins dictionary of the English language, 2nd ed. William Collins, Sydney.

8. Hebert, A. M., and R. H. Vreeland. 1987. Phenotypic comparison of halotolerant bacteria: Halomonas halodurans sp. nov., nom. rev., comb. nov. Int. J. Syst. Bacteriol. 37:347-350.

9. Holmes, B. 1991. The genera Flavobacterium, Sphingobacterium, and Weeksella, p. 3620-3630. In A. Balows, H. G. Trüper, M. Dworkin, W. Harder, and K. H. Schleifer (ed.), The prokaryotes, a handbook on the biology of bacteria: ecophysiology, isolation, identification, applications, vol. 4, 2nd ed. Springer-Verlag, New York.

10. Holmes, B., and R. J. Owen. 1979. Proposal that Flavobacterium breve be substituted as the type species of the genus in place of Flavobacterium aquatile and emended description of the genus Flavobacterium: status of the named species of Flavobacterium. Request for an opinion. Int. J. Syst. Bacteriol. 29:416-426.

11. Holmes, B., R. J. Owen, and T. A. McMeekin. 1984. Genus Flavobacterium, p. 353-361. In N. R. Krieg and J. G. Holt (ed.), Bergey's manual of systematic bacteriology, vol. 1. The Williams \& Wilkins Co., Baltimore.

12. Lane, D. J., B. Pace, G. J. Olsen, D. A. Stahl, M. L. Sogin, and N. R. Pace. 1985. Rapid determination of 16 S ribosomal RNA sequences for phylogenetic analyses. Proc. Natl. Acad. Sci. USA 82:6955-6959.

13. Merkel, J. R. 1972. Influence of salts on the vibriostatic action of 2,4-diamino-6,7-diisopropyl pteridine. Arch. Mikrobiol. 81: 379-382.

14. Olsen, G. J., N. Larsen, and C. R. Woese. 1991. The ribosomal RNA database project. Nucleic Acids Res. 19:2017-2021.

15. Pitcher, D. G., N. A. Saunders, and R. J. Owen. 1989. Rapid extraction of bacterial genomic DNA with guanidium thiocyanate. Lett. Appl. Microbiol. 8:151-156.

16. Reichenbach, H. 1989. Order 1. Cytophagales, p. 2010-2082. In J. T. Staley, M. P. Bryant, N. Pfennig, and J. G. Holt (ed.), Bergey's manual of systematic bacteriology, vol. 3. The Williams \& Wilkins Co., Baltimore.

17. Rosenburg, A. 1983. Pseudomonas halodurans sp. nov., a halotolerant bacterium. Arch. Microbiol. 136:117-123.

18. Saiki, R. K., D. H. Gelfand, S. Stoffel, S. J. Scharf, R. Higuchi, 
G. T. Horn, K. B. Mullis, and H. A. Erlich. 1988. Primerdirected enzymatic amplification of DNA with thermostable DNA polymerase. Science 239:487-491.

19. Sanger, F., S. Nicklen, and A. R. Coulson. 1977. DNA sequencing with chain-terminating inhibitors. Proc. Natl. Acad. Sci. USA 74:5463-5467.

20. Skerratt, J. H., P. D. Nichols, C. A. Mancuso, S. R. James, S. J. Dobson, T. A. McMeekin, and H. Burton. 1991. The phospholipid ester-linked fatty acid composition of members of the family Halomonadaceae and genus Flavobacterium. A chemotaxonomic guide. Syst. Appl. Microbiol. 14:8-13.

21. Stackebrandt, E. 1991. Unifying phylogeny and phenotypic diversity, p. 19-47. In A. Balows, H. G. Trüper, M. Dworkin, W. Harder, and K. H. Schleifer (ed.), The prokaryotes, a handbook on the biology of bacteria: ecophysiology, isolation, identification, applications, vol. 1, 2nd ed. Springer-Verlag, New York.

22. Stackebrandt, E., and O. Charfreitag. 1990. Partial 16S rRNA primary structure of five Actinomyces species: phylogenetic implications and development of an Actinomyces israelii- specific oligonucleotide probe. J. Gen. Microbiol. 136:37-43.

23. Swofiord, D. L. 1990. PAUP: phylogenetic analysis using parsimony, version 3.0. Illinois Natural History Survey, Champaign.

24. United States Biochemical Corporation. 1989. Step-by-step protocols for DNA sequencing with Sequenase version 2.0, 3rd ed. United States Biochemical Corp., Cleveland.

25. Weisburg, W. G., Y. Oyaizu, H. Oyaizu, and C. R. Woese. 1985. Natural relationship between bacteroides and flavobacteria. J. Bacteriol. 164:230-236.

26. Woese, C. R. 1987. Bacterial evolution. Microbiol. Rev. 51:221271.

27. Woese, C. R., S. Maloy, L. Mandelco, and H. D. Raj. 1990. Phylogenetic placement of Spirosomaceae. Syst. Appl. Microbiol. 13:19-23.

28. Woese, C. R., E. Stackebrandt, T. J. Macke, and G. E. Fox. 1985. A phylogenetic definition of the major eubacterial taxa. Syst. Appl. Microbiol. 6:143-151.

29. Woese, C. R., D. Yang, L. Mandelco, and K. O. Stetter. 1990. The flexibacter-flavobacter connection. Syst. Appl. Microbiol. 13:161-165. 